\title{
Going Down the Slippery Slope of Legitimacy Lies in Early-Stage Ventures: The Role of Moral Disengagement
}

\author{
Vasilis Theoharakis ${ }^{1} \cdot$ Seraphim Voliotis ${ }^{2}$. Jeffrey M. Pollack ${ }^{3}$
}

Received: 3 May 2019 / Accepted: 9 April 2020 / Published online: 20 April 2020

(c) The Author(s) 2020

\begin{abstract}
It would seem, on the surface, logical that entrepreneurs would treat stakeholders with honesty and respect. However, this is not always the case-at times, entrepreneurs lie to stakeholders in order to take a step closer to achieving legitimacy. It is these legitimacy lies that are the focus of the current work. Overall, while we know that legitimacy lies are told, we know very little about the psychological processes at work that may make it more likely for someone to tell a legitimacy lie. Thus, we theorize about the pressure to pursue legitimacy, the situational and individual factors that affect this pursuit, as well as how this context can lead to moral disengagement and the telling of legitimacy lies. Our theorizing advances the existing literature and provides a dynamic framework by which future research can delve more deeply into the nuanced context that breeds the escalation of legitimacy lies.
\end{abstract}

Keywords New ventures $\cdot$ Unethical decision-making $\cdot$ Legitimacy lies $\cdot$ Moral disengagement

\section{Introduction}

Entrepreneurs in early-stage ventures must earn the approval and support of key stakeholders in order to gain access to the resources needed for their venture's survival and growth (Uberbacher 2014). For this to be achieved, ventures need to attain legitimacy in order for their actions to be perceived as "desirable, proper, or appropriate" (Suchman 1995, p. 574). This implies that legitimacy attainment is a dichotomous state: either a stakeholder views a venture as legitimate or not legitimate which leads to the concept of a legitimacy threshold (Rutherford and Buller 2007). More specifically,

Vasilis Theoharakis

v.theoharakis@cranfield.ac.uk

Seraphim Voliotis

seraphim@voliotis.org

Jeffrey M. Pollack

jmpolla3@ncsu.edu

1 Cranfield School of Management, Cranfield University, Cranfield MK43 0AL, UK

2 ALBA Graduate Business School at the American College of Greece, Xenias 6-8, Athens, Greece

3 Management, Innovation, \& Entrepreneurship Department, Poole College of Management, North Carolina State University, Raleigh, NC, USA entrepreneurs need to surpass this legitimacy threshold and convince customers and financiers, the two most important stakeholders who hold the cash they need, to buy from the company and to finance it.

However, as some entrepreneurs intensely focus on attracting customers and securing financing, they may ignore other stakeholders in the venture's early legitimacy pre-threshold stage (Rutherford and Buller 2007, p. 82). Further, in their quest to overcome the liability of newness (Singh et al. 1986; Zott and Huy 2007) and achieve the much needed legitimacy, some entrepreneurs may intentionally misrepresent the facts and tell legitimacy lies (Rutherford et al. 2009). This process may result in a "slippery slope" (Baron et al. 2015, p. 107) since dishonesty facilitates the forgetting of moral rules and the justification of future dishonest acts (Shu et al. 2011).

Although stereotypes about entrepreneurial deception and the dark side of entrepreneurial leadership paint a potentially negative picture for some entrepreneurs (de Vries 1985), empirical studies have found entrepreneurs to hold more ethical attitudes and higher moral reasoning than managers (Bucar and Hisrich 2001; Teal and Carroll 1999). Nonetheless, there is one context in which some entrepreneurs have been shown to act, at times, deceptively. That is, at the very early pre-threshold stage of venture development, some entrepreneurs employ "whatever strategies and tactics" are 
Fig. 1 The unethical decisionmaking model for legitimacy lies

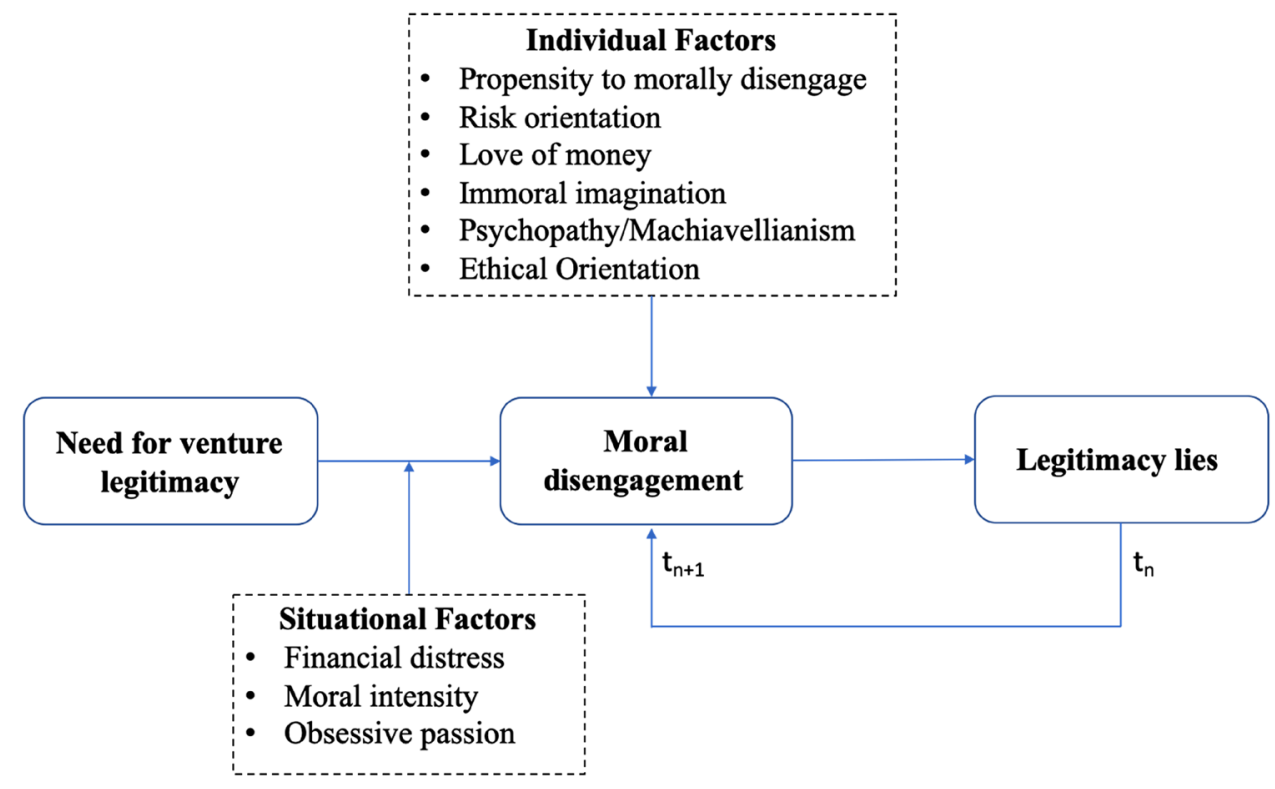

necessary in order to achieve legitimacy (Rutherford et al. 2009, p. 949). These practices challenge extant stakeholder theory which suggests that dealing with stakeholders in a respectful and honest manner builds trust and facilitates productive relationships (Pollack et al. 2017). Our aim in the present work is to examine factors that increase the likelihood of entrepreneurs to morally disengage and justify their lies when facing legitimacy pressures. The more entrepreneurs are enabled to morally disengage, the less likely they are to be regulated by their own moral sanctions, and thus more likely to act unethically (Baron et al. 2015). By taking a similar perspective, we focus on moral disengagement as a process and examine its mediating role in the delivery of legitimacy lies while also considering entrepreneurs' propensity to morally disengage (Moore 2015).

In building our theoretically based examination of legitimacy lies, we focus on entrepreneurs who engage in explicit and intentional misrepresentation of fact (i.e., lying), because therein resides an interesting question: How are entrepreneurs, who should be bound by moral constraints and treat all their stakeholders ethically, enabled to engage in deception? We provide an answer to this question by proposing a conceptual model that identifies multiple situational and individual psychological factors which enable entrepreneurs to override their internal moral sanctions and engage in deception in their effort to gain venture legitimacy. Here, our work offers many theoretical and practical insights.

First, we advance the literature by proposing a model that sheds light on the unethical decision-making process of entrepreneurs who consciously tell legitimacy lies. We focus on moral disengagement as our central mediating variable between the need for venture legitimacy and the intention to engage in legitimacy lies and also consider the most representative, relevant, and impactful factors that affect it, in order to produce an integrative, yet parsimonious model which is presented in Fig. 1. This model is based on a review of entrepreneurial leadership challenges (Kuratko 2007) and examines situational factors (moral intensity, obsessive passion for the venture, and financial distress) as well as individual psychological factors (propensity to morally disengage, the love of money, immoral imagination, the dark personality triad, risk and ethical orientations) that have been identified as important in the ethics and entrepreneurship literatures. It also considers the dynamic nature of the slippery slope since the commitment of an unethical act leads to moral deterioration, normalizes unethical behavior, and may influence future decisions (Moore and Gino 2015).

Our second contribution is that our approach addresses the call for examining entrepreneurial ethics (Brenkert 2009; Harris et al. 2009; Rutherford et al. 2009), especially with regard to new venture financing (Fassin and Drover 2017). As there is very little in the literature with respect to the mechanisms that enable entrepreneurial lying (Bryant 2009; McVea 2009), drawing on the extant research that focuses on unethical decision-making can improve our understanding in such environments (Treviño et al. 2014). In such a manner, we advance both the ethics and entrepreneurial decisionmaking literatures, as neither fully captures the nuances in this context or explicitly considers factors that are relevant for new ventures and the entrepreneurs who create them.

In the following sections, we expand on these contributions to the literature. First, we outline the theoretical and practical context of nascent ventures and their pressure to seek legitimacy. Then, we outline our conceptual model that ties situational and individual factors to the mediating role 
of moral disengagement in the relationship between the need for legitimacy and the intention to tell legitimacy lies, while also accounting for the slippery slope of such a process. In closing, we present the implications of our model.

\section{Theoretical Context: Legitimacy}

New venture legitimacy is broadly accepted as a crucial requirement for success and reflects the perception held by resource-holding audiences about the venture's propriety (Uberbacher 2014). Put succinctly, the undertaking of legitimacy generating activities reduces the threat of venture failure (Delmar and Shane 2004). The need to seek legitimacy originates from the liabilities of newness (LON) as well as liabilities of smallness (LOS) that plague nascent and emerging ventures (Rutherford et al. 2016). Overall, stakeholders are hesitant to engage with new and small ventures, which leads to a greater probability that nascent ventures will not acquire the information and needed resources to survive and grow (Bruderl and Schussler 1990; Kale and Arditi 1998). Thus, there is pressure on new and small ventures to attain legitimacy by any means possible.

Since investors will reject proposed ventures based on the characteristics of the entrepreneur and management team (Croce et al. 2017), it is important for a newcomer to gain legitimacy in order to be deemed as an entrepreneur (De Clercq and Voronov 2009). As a result, entrepreneurs need to surpass the legitimacy threshold that will enable them to receive needed capital and resources (Rutherford and Buller 2007; Rutherford et al. 2016; Zimmerman and Zeitz 2002). ${ }^{1}$

The literature has different perspectives as to how new venture legitimacy is achieved (Uberbacher 2014). One line of thinking is that fortune favors the prepared as demonstrated by the positive relationship between a well-prepared business pitch and venture financing (Pollack et al. 2012). However, this relationship is fully mediated by cognitive legitimacy which indicates the critical role of legitimacy in the survival of a new venture. We diverge from this approach as we seek to examine the psychological processes affecting the individual entrepreneur who takes an active role in the legitimation process. Thus, the most relevant legitimation perspectives for our study are (i) the micro-cultural, which

\footnotetext{
1 There are multiple different types of legitimacy-cognitive, regulative, normative, industry, etc. But, the current paper aims to delineate why entrepreneurs may or may not engage in legitimacy lies. Accordingly, the specific types of legitimacy entrepreneurs are pursuing are beyond the scope of our paper. However, for citations to related work on the specific topic of legitimacy types see, for example, Bitektine (2011), Bitektine and Haack (2015), Rutherford et al. (2016) and Suddaby et al. (2017).
}

is based on storytelling, and (ii) the impression management perspective.

Although storytelling and impression management have a great deal in common, entrepreneurial storytelling relates to the development of a new identity rather than the enhancement of an established identity (Lounsbury and Glynn 2001). Given the fluid or non-existent identity of young entrepreneurial ventures, effectively constructed stories have been empirically found to help entrepreneurs acquire the funds they seek (Martens et al. 2007). Nonetheless, several studies have also taken an impression management approach for examining new venture financing (Nagy et al. 2012; Parhankangas and Ehrlich 2014).

Over time, entrepreneurs become more skillful at building legitimacy: while they initially focus on "what matters to me" they eventually strike a balance with "what matters to me and them" by recognizing the need to address a more diverse audience (O’Neil and Ucbasaran 2016). However, individuals engage in socially desirable responding (Zerbe and Paulhus 1987) when they present themselves favorably with respect to current social norms and standards. In this manner, they seek to conform to what is expected by external audiences who are evaluating them and may use impression management in order to deceive (Weiss and Feldman 2006). In particular, entrepreneurs feel the pressure to demonstrate to external audiences the "propriety" of their new venture by conforming to the standards expected by investors (e.g., high returns) or customers (e.g., unique selling proposition). Overall, the narrative of entrepreneurial stories and impression management activities can be fraught with deceitful practices due to the underlying legitimacy pressures (Pollack and Bosse 2014) that might make the difference between the survival and death of the venture.

\section{The Unique Context of Early-Stage Ventures}

Since what is judged as ethical or unethical depends, to a large extent, on the specific context and individual perceptions (Carlson and Kacmar 1997), early-stage ventures provide a unique context for examining unethical behavior (Conroy et al. 2017). Here is what the context looks like.

Imagine an entrepreneur who has an idea and maybe even a sense of how to develop a unique value proposition that can provide substantial customer value. But, in order to execute on this value proposition, the entrepreneur needs to convince key stakeholders to support the nascent venture. As a result, the individual entrepreneur engages in impression management (Parhankangas and Ehrlich 2014) and storytelling (Garud et al. 2014) with the purpose of establishing new venture legitimacy. However, the morality embedded in the narrative of these entrepreneurial tales can vary greatly (Smith and Anderson 2004). Accordingly, as entrepreneurs struggle to survive, they may not benefit from the moral 
guidance that might be available in established organizations (Ashforth and Anand 2003), even though not all established organizations are necessarily ethical and entrepreneurs may draw from past experience in established organizations. ${ }^{2}$ Under these circumstances, some entrepreneurs may choose to act immorally and lie intentionally if such lies will ensure the survival of the firm, secure the position of the entrepreneur, and increase the public visibility of the firm (Morris et al. 2002).

In the specific context of nascent ventures, when entrepreneurs engage with investors and prospective customers, informational asymmetries arise which can facilitate deception (Fassin and Drover 2017; Kriss et al. 2013). For example, entrepreneurs might understand more about a specific technology and its benefits or may have insights into the market that they choose not to share with stakeholders. Nonetheless, a financial power asymmetry may also exist when potential financiers (e.g., angel investors, VCs), have considerably more financial leverage than the new venture entrepreneurs they are evaluating. This financial power asymmetry further strains the entrepreneur-stakeholder relationship, making entrepreneurs potentially experience high levels of tension in maintaining control of the narrative (Fassin and Drover 2017). At a time when entrepreneurs lack legitimacy, information asymmetries and a financial power differential create a conducive environment for entrepreneurs to deceive. Overall, entrepreneurs may be tempted to lie due to their motivation to conform to investor expectations and gain the financial resources needed (Pollack and Bosse 2014). Indeed, Guy Kawasaki-a prominent entrepreneur, author, and investor-is fond of noting that, "If an entrepreneur's lips are moving, they are probably lying" (Alboher 2008).

\section{Legitimacy Lies and Deception}

In order to analyze legitimacy lies from an ethical decision-making lens, we need to clarify the notions of lie and deception. As one would expect, there is a lengthy debate in philosophy which is considerably more abstract than our current focus warrants (Martin 2009). However, the field of law provides a practical, clear, and nuanced analysis of lies and deception which is coupled with the notion of legal culpability. Depending on the circumstances, one may lie outright (lie by commission) or may hide vital information (lie by omission), both of which are intentional behaviors for the purpose of deceiving a stakeholder. This classification stems from a fundamental distinction recognized in the law of deception, and criminal law in general: culpable action and culpable inaction (Ormerod and Laird 2018).

$\overline{2}$ We thank an anonymous reviewer for this comment.
While culpability resides with intentional acts that cause harm, there are circumstances where an omission may also be culpable, the general rule being whenever there is a special relation between the parties, such as a contractual duty or a fiduciary duty (Ormerod and Laird 2018).

In the context of entrepreneurial deception, we take the perspective that entrepreneurs could be considered culpable for omitting to share relevant information as they may owe a particular duty of care to existing and prospective stakeholders. However, such a duty from a legal perspective would depend on the nature of the relationship with the stakeholder. For instance, there appears to be no such duty towards financers who are in early discussion stages and have not yet entered in any legal agreement, but there could be a duty towards financers who have become company shareholders. Nonetheless, omitting information with regard to a customer can be considered as a misleading and an unfair commercial practice in a wide range of legal systems that seek to protect consumers (Katuoka and Navickaitė-Sakalauskienè 2016).

The nature of the relationship between entrepreneurs and their stakeholders is also relevant to lies by commission. ${ }^{3}$ As already noted, lying relies on the asymmetry of information which naturally varies between stakeholder classes. ${ }^{4}$ On one hand, early investors typically hold less information about the company as the company has had less time to interact with the market and test its value proposition. On the other hand, investors in later stages are more likely to have access to more direct and reliable information as there should be more tangible evidence in terms of the team's product and market development capabilities. One would thus expect a higher instance of entrepreneurial lies in the former case versus the latter.

Moreover, impression management or story telling do not necessarily entail deception and lies in their usual form; they may emphasize the beneficial aspects of the new venture and downplay others (Uberbacher 2014). Entrepreneurs may even use overly complex or technical language as a camouflage to make their communication less transparent (Benson et al. 2015). Interestingly, another more sophisticated type of lie is paltering, which involves the purposeful use of truthful statements that are misleading within a particular context in order to create a mistaken impression (Rogers et al. 2017). However, impression management and storytelling

\footnotetext{
3 The topic of which stakeholders are needed by entrepreneurs at which point in the life cycle of a venture is a complicated area of inquiry (for a review, see Pollack et al. (2017). In the present work, we focus specifically on the pre-threshold phase of the venture life cycle. And, in this particular context the stakeholders whom are most important are customers and financiers.

${ }^{4}$ We thank one anonymous reviewer for raising this issue.
} 
in entrepreneurial financing also entail the widespread use of hypotheses and assumptions on which presentations and valuations are invariably based. ${ }^{5}$ These assumptions may include predictions of future outcomes, such as economic growth, technological development, or even geo-political conditions, most of which are notoriously difficult to predict. Typically, investors expect from entrepreneurs the analysis of scenarios (pessimistic, expected, or optimistic), precisely because of the speculative nature of these endeavors. As a result, we do not in general consider over-optimism a form of legitimacy lie. We could, of course, envisage situations where intentional misrepresentations of fact could be masqueraded as "assumptions" (e.g., the knowing underestimation of the technological advances of a potential competitor). However, insofar as genuine assumptions are concerned, our considerations stand even if they are manifestly overoptimistic or misguided. Ultimately, this classification relies on the more fundamental distinction between "fact" and "opinion" which is also recognized in the law of deception (Ormerod and Laird 2018).

Since entrepreneurs may not even perceive their deceptions as lies, but "as a simple act of survival" (Feifer 2018, p. 24), we conclude our brief review of lying and deception, by drawing on the general principles of legal analysis in order to refine the concept of lie. While we stress that what constitutes a lie is heavily nuanced and contextualized, we consider lies to be intentional behaviors for the purpose of deceiving a stakeholder.

\section{Rules and Rule-Breaking}

Entrepreneurs are sometimes described as rule-breakers who may treat current structure and moral rules as constraints, but without their creative, bold, and devious acts, a number of companies and products would not have existed (Brenkert 2009; de Vries 1977). While rule-breaking and breaking the law are different issues, both creativity and immorality may entail some form of rule-breaking, although the former tends to be evaluated positively whereas the latter negatively (Gino and Wiltermuth 2014). There is also evidence that creative people are more likely to break laws (Cropley et al. 2013; Sternberg and Lubart 1995; Sulloway 1996) or to engage in deception (Beaussart et al. 2013; Gino and Ariely 2012).

Therefore, there are practical implications for creative entrepreneurs who often find themselves constrained by moral rules to control any deceptive practices. This is where we focus the remainder of our theorizing as we outline a theory-based model that can account for the phenomenon of legitimacy lies. In sum, it is important that we understand

\footnotetext{
$\overline{5}$ We would like to thank an anonymous reviewer for highlighting this distinction.
}

the process that leads otherwise ethical, legitimacy seeking, entrepreneurs to engage in deceptive behaviors. Similar to other studies that have examined unethical behavior (Jones and Kavanagh 1996), we identify a set of situational characteristics and a set of individual characteristics that enable the entrepreneur to engage in legitimacy lies.

\section{Moral Disengagement}

Entrepreneurs with some degree of moral sensitivity will invariably recognize that legitimacy lies are immoral, but may nevertheless engage in the contemplated action provided they overcome their internal moral sanctions and justify to themselves that such action is appropriate. In other words, the external propriety of their venture may be established by a legitimacy lie and the internal propriety of the lie may be established by a psychological process called moral disengagement which allows moral sanctions to be lifted (Bandura 1999; Bandura et al. 1996; Baron et al. 2015). Therefore, while a legitimacy lie seeks to establish the propriety of the venture in the eyes of external stakeholders, moral disengagement is the internal psychological mechanism employed by entrepreneurs to establish the propriety of such an immoral act to themselves. Since moral disengagement is used by individuals who would rather not behave unethically, it is a critical and central component of our model-it explains how otherwise honest entrepreneurs succumb to new venture legitimacy pressures and justify their act of embellishing their stories with legitimacy lies. ${ }^{6}$

We chose to focus on moral disengagement rather than related concepts such as justification, neutralization, or rationalization because these terms are often used interchangeably. In contrast, moral disengagement appears to be defined more precisely, to be theorized more extensively in psychological terms (Bandura et al. 1996), and to be well studied in a broad array of domains (Moore 2015) and entrepreneurship in particular (Baron et al. 2015). The concept of neutralization was introduced by Sykes and Matza (1957) in order to highlight the internal process juvenile delinquents engage in order to overcome self-blame from internalized norms. This is clearly a very similar concept to moral disengagement, if not the same (Ribeaud and Eisner 2010), albeit stemming from a sociological tradition. Ashforth and Anand (2003) use these concepts interchangeably as prospective rationalizations of corrupt behavior. Similarly, Aguilera and Vadera (2008) rely on all the above in order to explain how ex ante justifications enable corruption. Interestingly, in his integrative model of ethical decision-making Schwartz

\footnotetext{
${ }^{6}$ For multiple examples of legitimacy lies, see Pollack and Bosse (2014) as well as Rutherford et al. (2009).
} 
Table 1 Examples of entrepreneurial moral disengagement

\begin{tabular}{ll}
\hline Type of moral disengagement & Entrepreneurial justification \\
\hline Palliative comparison & Everybody does it \\
& This is nothing compared to what Enron (or XYZ) did \\
Euphemistic labeling & Not really a fact but an opinion \\
Minimization of consequences & Investors expect lies and therefore discount them \\
Displacement of responsibility & Without it we cannot survive in this cut-throat environment \\
Diffusion of responsibility & All members of our team have agreed to it \\
Dehumanization & The rich, greedy, and self-centered investors deserve what they get \\
Blaming the victim & They do not believe us anyway so what is the point of underselling our venture \\
& They should have performed due diligence \\
Moral justification & We have a responsibility towards our employees (or previous funders) and to \\
& each other to do whatever it takes \\
\hline
\end{tabular}

(2016) invokes both Sykes and Matza (1957) and Bandura (1999) as a basis of the moral rationalization construct.

Bandura's (1986) systematic treatment of moral disengagement identifies the following types: (a) euphemistic labeling, which is simple exaggerations or points of view; (b) minimization of consequences, which seeks to demonstrate that the consequences of the proposed act are not serious; (c) displacement of responsibility, which seeks to attribute the act to an external cause; (d) diffusion of responsibility, which apportions blame to multiple sources; (e) victim dehumanization or blame, which attributes the blame to the victim or which denies the victim moral status; (f) palliative comparison, which favorably compares the proposed act to much larger wrongs; and (g) moral justification, which demonstrates that the proposed act may serve an alternative, and possibly higher, moral purpose. Table 1 gives typical examples of these types of moral disengagement, within the entrepreneurial context.

Overall, with the juxtaposition of legitimacy lies and moral disengagement, we aim to explain what appears to be a paradoxical and interesting situation: when entrepreneurs seek to gain external propriety for their venture by engaging in the improper act of legitimacy lies, this generates the need for internal propriety which can be achieved by moral disengagement. If successful, the process will render the immoral legitimacy lie as proper to the entrepreneur, and in turn the legitimacy lie may render the venture proper to the investor or relevant stakeholder.

\section{Moral Disengagement and Entrepreneurial Deception}

Ethical decision-making models explain how an individual may engage in ethical behavior despite strong motives to behave otherwise (Jones 1991; Rest 1986). However, here we are concerned with unethical behavior and, in particular, how an entrepreneur may engage in deception. In a meta-analysis conducted on unethical behavior (KishGephart et al. 2010), only one of the papers used in the main analysis relates to entrepreneurship (Neubaum et al. 2004). Also, no references are drawn from a new venture context in a review of (un)ethical behavior (Treviño et al. 2014). In other words, there appears to be a knowledge gap with respect to the psychological mechanisms that precipitate the entrepreneur's decision to lie, although Baron et al. (2015) find that moral disengagement does lead entrepreneurs to unethical decisions.

As noted earlier, Bandura et al. (1996) conceptualizes moral disengagement as a process that selectively disengages the moral self-sanctions raised after a negative moral evaluation, and precedes the intention to act immorally. This moral disengagement process is modeled as a mediator between the incentive to act immorally and the intention to act (Moore 2015). It follows that, in the present context, moral disengagement as a process has a mediating effect on the link between the entrepreneurs' need for legitimacy and their intention to employ legitimacy lies. Therefore, given that an increased need for legitimacy is broadly accepted to increase the pressure for deception (Rutherford et al. 2009), we propose the following relationship (see Fig. 1).

Proposition 1 Moral disengagement as a process mediates the effect of the need for venture legitimacy on the formation of the intention to lie.

\section{Factors Affecting Moral Disengagement}

Extant research on moral disengagement reveals a large number of constructs that affect moral disengagement (Moore 2015). Overall, we know that outlining the moral disengagement process, encouraging critical thinking, and highlighting harm have the potential to reduce unethical behavior (Gino and Margolis 2011). Thus, given what we 
already know, we sought to identify specific constructs relevant for an early-stage entrepreneurial venture context.

We follow other ethical decision-making models and identify situational and individual factors that affect moral disengagement within a new venture context (Schwartz 2016). We examine how the entrepreneur's process to morally disengage and ultimately express legitimacy lies depends on the situation that may amplify the need for legitimacy and the individual characteristics of the entrepreneur. This is also consistent with the dual role of moral disengagement which "can be understood both as a relatively stable cognitive orientation" which is individual in nature and also "as a state triggered by more immediate contextual factors" (Moore 2015, p. 202). In our theoretical development, we are guided by Kuratko's (2007) editorial about entrepreneurial leadership and his concern about the darker side of entrepreneurship which consists of confronting risk, entrepreneurial stress, and the entrepreneurial ego. While Kuratko (2007, p. 5) acknowledges that not all entrepreneurs fall victims of the darker side, he claims that it is important to "recognize the idiosyncrasies of entrepreneurial behavior." He describes entrepreneurship as taking place in a chaotic environment where creativity and passion are portrayed to have a central role in a struggle to gain resources through the presentation of a business plan to investors.

Thus, on the situational side, we examine (a) financial distress (Proposition 2), (b) moral intensity (Proposition 3), and (c) obsessive passion for the venture (Proposition 4). On the individual-level side, we examine (a) the propensity of an individual to morally disengage (Proposition 5), (b) the ethical implications of risk-taking as an essential component of entrepreneurial orientation (Proposition 6), (c) the entrepreneur's love of money as a very self-centered view about gaining financial resources (Proposition 7), (d) immoral creativity as a negative use of creativity (Proposition 8), (e) the entrepreneurial ego as represented by the well-established dark personality traits (i.e., psychopathy, Machiavellianism) (Proposition 9a, 9b), and (f) ethical orientation (Proposition 10a, 10b). Finally, we examine the slippery slope of legitimacy lies (Proposition 11).

\section{Situational Factors of Moral Disengagement}

As recently described by Miska et al. (2018), we conceptualize the situational context as moderating the process leading to unethical behavior. More specifically, we propose that at the same levels of need for legitimacy, a differing likelihood of moral disengagement will be experienced depending on situational factors.

\section{Financial Distress}

The struggle for resources and support are a root cause for entrepreneurial stress which is one of the darker components of entrepreneurial leadership (Kuratko 2007). While entrepreneurial stress is individual in nature and may also be at play, we focus on the contextual cause that is more objective in nature which directly relates to a venture's lack of resources and support: financial distress. The relevance of financial distress is exemplified by the ubiquitous concern about the "venture's runway," i.e., the months until the venture depletes its cash reserves. When a cash-depleted venture requires a financing round in order to avoid the severe consequences of bankruptcy, partnering with unethical investor becomes considerably more likely (Drover et al. 2014). This demonstrates that moral standards are more likely to be reduced for the venture in distress. Overall, the occurrence of financial distress is also linked with fraudulent communications and reporting by large public firms (Rezaee 2005). Financial distress is not treated here as an individual factor because it does not refer to an individual trait that characterizes the entrepreneur, but is rather a situational factor that relates to the venture's financing; such a situation may provide the entrepreneur with ample justification to morally disengage.

Within our context we suggest that, for any given level of need for venture legitimacy, the higher the level of financial distress, the higher the likelihood for engaging in a moral disengagement process. We therefore propose the following:

Proposition 2 Financial distress positively moderates the relation between the need for venture legitimacy and moral disengagement.

\section{Moral Intensity}

The importance of entrepreneurs to hold "moral principles" that will help them navigate through the ethical "tenuous balance" they often face when trying to "overcome many of the organizational obstacles" has been noted (Kuratko 2007 , p. 7). Moral intensity is a contextual factor where the characteristics of the issue reflect the "moral imperative in a situation" (Jones 1991, p. 372) that entrepreneurs may consider when balancing the situation. As it is linked to more sophisticated moral reasoning, Jones (1991) decomposes moral intensity into six factors which have different levels of impact (McMahon and Harvey 2006; Tsalikis et al. 2008). One of these factors is the magnitude of consequences as perceived by the moral agent, which Jones defines as "the sum of the harms (or benefits) done to the victim (or beneficiaries) of the moral act in question" (Jones 1991, p. 374). 
Table 2 Decomposition of moral intensity in an entrepreneurial context

\begin{tabular}{|c|c|}
\hline Moral intensity factor & Level of moral intensity \\
\hline Magnitude of the consequence & $\begin{array}{l}\text { Higher when dealing with FFF vs. professional investors-FFF are less likely to discount the lie and their } \\
\text { investment is likely to represent a larger part of their assets }\end{array}$ \\
\hline Probability of causing harm & Higher when dealing with FFF vs. professional investors \\
\hline Social consensus & $\begin{array}{l}\text { Lower for professional investors who expect legitimacy lies to be part of the landscape, but higher for FFF } \\
\text { investors because legitimacy lies breach trust }\end{array}$ \\
\hline $\begin{array}{l}\text { Social, psychological, and cultural } \\
\text { proximity }\end{array}$ & $\begin{array}{l}\text { Higher for FFF that are expected to be more proximate, but lower for professional investors and crowd fund- } \\
\text { ing investors who are less proximate; proximity with professional investors, may increase depending on the } \\
\text { relationship developed }\end{array}$ \\
\hline Temporal distance & Lower for investors due to the expected lag between financing and investment review milestones \\
\hline Concentration of the effect & $\begin{array}{l}\text { Lower for crowdfunding investors and higher for FFF due to the potential number of individuals affected by } \\
\text { the deception and lower when entrepreneur views the funding entity as a large anonymous organization } \\
\text { with a diverse investment portfolio and higher if it focuses on the small investment team that might be } \\
\text { supporting them }\end{array}$ \\
\hline
\end{tabular}

Overall, these factors relate to our entrepreneurial context and depend on those who could be harmed. For example, the moral intensity of the situation will depend on if the financiers are professional investors, such as VCs and angel investors, or inexperienced Friends, Family, and Fools (the FFF that often serve as the initial source of funding, and anonymous crowd funding investors). In general, when the investors are FFF who are more likely to be proximate and possibly less experienced, an individual entrepreneur is more likely to experience higher levels of moral intensity (Table 2). Besides investors, a similar line of thinking applies to the venture's customers where moral intensity would be higher when small, more vulnerable, and familiar customers are involved versus selling to large, wellresourced, and impersonal businesses.

In their meta-analysis, Kish-Gephart et al. (2010) confirmed Jones's (1991) hypothesis that higher moral intensity decreases the likelihood that an individual engages in unethical behavior. Indeed, the more morally intense a contemplated unethical act is (i.e., the larger, the sooner, or more probable, proximate, concentrated, socially frowned upon its negative consequences are), the more likely it will be for the actor to evaluate it as immoral, and accept responsibility for its consequences. This is likely to raise self-sanctions further, and thus, for any given level of need for legitimacy, the more morally intense the situation the less likely it will be for an entrepreneur to morally disengage. In sum, while this effect is likely to be complicated by the type of investor or customer involved (see Table 2), we propose the following:

Proposition 3 The moral intensity of the contemplated lie negatively moderates the relationship between the need for venture legitimacy and moral disengagement.

\section{Obsessive Passion for the Venture}

Kuratko (2007, p. 3) provides a definition of entrepreneurship that highlights it as a dynamic process which requires passion. The passion displayed by entrepreneurs is one of the most frequently observed phenomena of the entrepreneurship process (Smilor 1997). Entrepreneurial passion is also a key element that investors seek when making new investment decisions (Murnieks et al. 2016). Overall, entrepreneurial passion is linked with entrepreneurial effectiveness by enhancing goal-oriented cognitions (e.g., goal commitment) and entrepreneurial behaviors (e.g., creative problem solving, persistence) (Cardon et al. 2009). However, the purported positive effects of passion may mislead investors into indiscriminately seeking passionate entrepreneurs, notwithstanding that passion may actually not yield benefits or can even have "debilitating" effects (Cardon et al. 2005; Ho and Pollack 2014).

It is also important to clarify that passion as described by the dualistic model of passion is not a general trait but depends on the activity itself (Vallerand et al. 2003). More specifically, passion for an activity can be an autonomous process that results in harmonious passion or be an uncontrolled process that takes the form of obsessive passion. While harmonious passion reflects that the person has freely chosen the activity which is in harmony with other aspects of the person's life, obsessive passion reflects a compulsion to engage in the activity. Although one would expect the former to be a more sustainable and desirable form of passion, angel investors demonstrate a preference for obsessive passion over harmonious passion when they evaluate a proposed venture (Murnieks et al. 2016). On the other hand, entrepreneurs who are obsessively passionate with a particular venture are less likely to be approached by peers and receive less business income and less referrals in contrast to entrepreneurs who are harmoniously 
passionate with a venture and received more referrals and business income (Ho and Pollack 2014). Further, entrepreneurs who are obsessively passionate with a venture are more likely to engage in unethical pro-organizational behavior while those with harmonious passion are more likely to abstain from it (Kong 2016).

Following the dualistic model of passion, we consider obsessive passion to be contextual: it is not a personal trait that characterizes an entrepreneur across all life activities or ventures, but is specific to the venture at the time of examination. For example, an entrepreneur involved in different ventures does not necessarily share the same obsessive passion across ventures. Further, the obsessive passion of an entrepreneur may also change even for the specific venture across time: in the event of a significant stock dilution or increased control by investors, the entrepreneur might lose their obsessive passion that characterized them during earlier stages. Overall, we expect that due to their obsessive passion with the specific venture, the entrepreneur is more likely to prioritize the venture's viability over moral constraints. Therefore, for any given level of venture legitimacy need, the more obsessively passionate entrepreneur may be more likely to disengage morally in order to overcome their self-sanctions. Accordingly, we propose the following:

Proposition 4 Obsessive passion for a venture positively moderates the relationship between the need for venture legitimacy and moral disengagement.

\section{Individual Factors of Moral Disengagement}

We now consider how entrepreneurs' psychological traits may affect the ease of moral disengagement which in turn affects the likelihood of legitimacy lies. We focus on the effect that propensity to morally disengage, risk orientation, love of money, immoral imagination, and the Dark Triad of personality traits (i.e., narcissism, psychopathy, and Machiavellianism) have on moral disengagement.

\section{Propensity to Morally Disengage}

Moral disengagement can also be viewed as a disposition describing the propensity of an individual to morally disengage (Moore et al. 2012). It is therefore expected that a "high dispositional moral disengagement will amplify unethical behavior" (Moore 2015, p. 201). This implies that for any given level of venture legitimacy, an entrepreneur with a higher propensity to morally disengage will be more likely to engage in a moral disengagement process and therefore lie. ${ }^{7}$

\footnotetext{
7 We would like to thank an anonymous reviewer for highlighting this issue.
}

Proposition 5 Entrepreneurs exhibiting higher levels of moral disengagement as a disposition are more likely to activate a moral disengagement process.

\section{Risk Orientation}

Risk is an essential element of entrepreneurial activity, evidenced by the inclusion of risk orientation as a component of entrepreneurial orientation (Covin and Slevin 1989). However, entrepreneurial risk may hide a dark side (Kuratko 2007) since it is associated with greater performance expectations and greater variability in outcomes (Karmann et al. 2016). Karmann et al. (2016, p. 227) argue that risk-taking's increased outcome variability makes it more likely for agents to be tempted in corruption. Their empirical results demonstrate that risk orientation is the only factor of entrepreneurial orientation associated with organizational corruption - they refer to risk orientation as the "darker side" of entrepreneurial orientation (p. 231).

Although creating a risk-taking culture may increase creativity, it may also have implications with regard to ethical issues (Baucus et al. 2008). Since risk-taking is also associated with higher performance expectations, it is more likely to result to ethical dilemmas that may favor lifting moral sanctions in favor of achieving aggressive targets. We therefore propose that:

Proposition 6 Entrepreneurs with higher levels of risk orientation are more likely to activate a moral disengagement process.

\section{Love of Money}

Entrepreneurial rewards and success are frequently celebrated (Kuratko 2007, p. 5). The importance an entrepreneur places on financial success is a key determinant explaining growth preferences, the intended size and achieved growth of the venture, and the willingness to take higher levels of risk (Cassar 2007). However, the greed of entrepreneurial leaders, i.e., their desire for, and active pursuit of, extraordinary material wealth can have a detrimental effect on other stakeholders and is particularly deleterious for new startup ventures (Haynes et al. 2015). An aspect of such a desire for wealth, has been operationalized as the love of money which leads to unethical behavior (Tang and Chiu 2003) and predicts cheating (Chen et al. 2014). Further, love of money results in objectification (Wang and Krumhuber 2017), which refers to the treatment of others as objects or instruments (Nussbaum 1995). Objectification is an act of dehumanization that involves the denial of a person's human nature (Haslam 
2006), which is an integral component of moral disengagement as defined by Bandura et al. (1996) (see Table 1). As Ariely (2008, p. 24) observes, we very easily rationalize our dishonest actions when such a dishonest action will have immediate monetary rewards. More specifically, since an entrepreneurs' motivation for financial gains is positively related to moral disengagement (Baron et al., 2015), we propose that the following:

Proposition 7 Entrepreneurs with higher levels of love of money are more likely to activate a moral disengagement process.

\section{Immoral Imagination}

The entrepreneurial spirit is characterized by imagination, creativity, novelty, and sensitivity; it takes imagination and creativity to develop new solutions for existing or new problems (Buchholz and Rosenthal 2005; Kuratko 2007). In this context, moral imagination has been described as a quality which allows a person to become sensitive to a wide range of factors around business decision-making that may generate harm. According to McVea (2009, p. 491), moral imagination enables decision-makers to combine their creativity with ethical rigor in order to overcome the constraints of rule-based ethical frameworks. He adopts Moberg and Seabright's (2000) conceptualization and finds, inter alia, that entrepreneurs exhibit a high degree of moral imagination and could thus generate alternative courses of action that loosen the constraints of the problematic situation.

However, Seabright and Schminke (2002) note that the definition of moral imagination is valence-neutral and could apply equally well to imagination that fosters immoral activity. Their conceptualization of immoral imagination focuses on forms of evil that are ends in themselves (revenge and sadism). However, according to Baumeister (1996), evil, and by association immorality and immoral imagination, also entails harm as means to an end (greed, ambition, and idealism). Such a holistic view of immoral imagination makes it particularly relevant to our model, because entrepreneurial deception is a means towards legitimacy, rather than an end to itself. Following Seabright and Schminke's (2002) conceptualization, immoral imagination could generate alternative courses of action that loosen the constraints imposed by self-sanctions, in other words, enable moral disengagement. In particular, immoral imagination prompts immoral action by dehumanizing others and, as noted earlier, such dehumanization is a typical form of moral disengagement. Entrepreneurs who exhibit high degrees of immoral imagination are more likely to generate imaginative ways to disengage from the moral charge of the proposed deception. More formally, we propose the following:

Proposition 8 Entrepreneurs with higher levels of immoral imagination are more likely to activate a moral disengagement process.

\section{Dark Triad of Personality Traits}

Entrepreneurs are known to be different in regard to the Big Five personality traits when compared with managers; these traits are also relevant in predicting entrepreneurial intention, activity, and performance (Brandstätter 2011; Leutner et al. 2014). However, attention has been raised on the entrepreneurial ego as a darker side of entrepreneurial leadership (Kuratko 2007), and a call for studying the negative side of the entrepreneurial personality has also been made (Miller 2015). The Dark Triad of personality traits is comprised of three malevolent and ego-centric characteristics: psychopathy, Machiavellianism, and narcissism (Paulhus and Williams 2002). While these personality traits are commonly found among business leaders and politicians, some have been linked with unproductive (i.e., value appropriating, rent seeking) entrepreneurial motives of early-stage nascent entrepreneurs among a sample of business students (Hmieleski and Lerner 2016).

Psychopathic individuals are characterized by lack of affective empathy, but their cognitive empathy enables them to understand what motivates others and makes them very capable in manipulating them (Hmieleski and Lerner 2016). In its primary psychopathy form, individuals are also characterized as being shallow and unable to accept responsibility, while in its secondary form individuals are impulsive, seek stimulation, and have antisocial tendencies such as criminal versatility, delinquency, and likelihood to reoffend (Levenson et al. 1995). Babiak et al. (2010) find corporate psychopathy to be positively associated with key elements of impression management such as charisma and presentation style reflecting creativity, good strategic thinking, and communication skills, but negatively associated with being a team player, management skills, and overall accomplishments. With entrepreneurs being stereotyped as corporate psychopaths (Akhtar et al. 2013), Stevens et al. (2012) find that psychopathy in a business context positively relates to moral disengagement. This is consistent with other studies that find psychopathy to predict lying (Roeser et al. 2016), positively correlate with moral disengagement (Egan et al. 2015) or with unproductive entrepreneurial motives (Hmieleski and Lerner 2016).

Individuals who exhibit high levels of Machiavellianism use deceit and manipulation in order to achieve their own goals with disregard to the needs of others (Christie and 
Geis 1970). While they are cynical and have a strong need for money and power, they are socially skillful and may even exhibit helping behaviors as part of their manipulation for self-gain (Hmieleski and Lerner 2016; Kessler et al. 2010). As a result of their broader view that the ends justify the means, Machiavellian individuals quickly engage in deviant behaviors and unethicality is an integral part of the trait (Côté et al. 2011; Dahling et al. 2009). Further, Machiavellians use impression management rather indiscriminately and use more risky and more deceptive forms of it; they do not use impression management to please others, but to achieve their own ends (Bolino and Turnley 2003). Moreover, their selfishness appears to enhance their engagement in pro-organizational unethical behaviors as they tend to abandon ethical standards and value manipulative behavior (Castille et al. 2018).

Narcissistic individuals are self-centered, seek attention, admiration, and applause, and maintain an exaggerated self-concept about their importance and influence (Twenge et al. 2008). Although narcissism appears to be a trait that is consistently increasing over time, when Twenge et al. (2008) reviewed the relevant literature, they found narcissism to be linked with a range of positive emotions such as self-esteem, positive affect, extraversion, and life satisfaction. Further, they also describe narcissism to be associated with short-term (but not long-term) likeability, enhanced performance in public tasks, and short-term victories in competitive tasks. It is therefore not a surprise that narcissistic individuals are judged to be more successful in pitching creative ideas, not necessarily because they are more creative, but because they were more enthusiastic and appear more charismatic (Goncalo et al. 2010). Zuo et al. (2016) describe narcissism as the brightest of the Dark Triad and find it to be positively related to internalization and symbolization, the two dimensions of moral identity that motivate moral action (Aquino and Reed 2002). It is therefore plausible that while narcissistic entrepreneurs enthusiastically pitch their new ideas and seek to be applauded, this is done while maintaining a moral compass. Although concerns have been raised about the narcissistic predisposition of leaders in general (de Vries and Miller 1985), narcissistic CEOs demonstrate a propensity for higher levels of entrepreneurial orientation (Wales et al. 2013), i.e., seek higher levels of proactiveness, innovation, and risk-taking (Covin and Slevin 1989). More relevant to our context, narcissistic individuals demonstrate higher levels of entrepreneurial intention and are linked with productive entrepreneurial motives (Hmieleski and Lerner 2016). Overall, narcissism does not predict moral disengagement nor unethical attitudes and behavior (Egan et al. 2015; Roeser et al. 2016). In summary, narcissism is described as the least malevolent among the dark personality traits, while narcissists as the least vulnerable to moral disengagement (Roeser et al. 2016, p. 76). Accordingly, we do not include it in our model.

Hence, in our examination of the individual Dark Triad traits, we focus on psychopathy and Machiavellianism as related to unproductive/value appropriating entrepreneurial behavior among nascent entrepreneurs (Hmieleski and Lerner 2016) and moral disengagement (Egan et al. 2015). We therefore propose the following:

Proposition 9a,b Entrepreneurs with higher levels of (a) psychopathy, and (b) Machiavellianism are more likely to activate a moral disengagement process.

Proposition 9c Entrepreneurs with higher levels of (c) narcissism are not more likely to activate a moral disengagement process.

\section{Ethical Orientation}

We conclude our theorizing with a fundamental distinction in the ethical orientation (O'Fallon and Butterfield 2005) of entrepreneurs. Ethical orientations are predispositions of individuals engaging in moral evaluations to favor a particular ethical framework over another. Two of the most prominent ethical orientation frameworks, which are often contrasted with one another as polar opposites, are the deontological and the consequentialist frameworks. On one hand, a deontological orientation assesses an act normatively based on a predetermined set of accepted rules that define what is proper (Rawwas et al. 2005). On the other hand, a consequentialist orientation assesses the act based on the good (or harm) it causes and to whom (Chakrabarty and Bass 2015).

Rutherford et al. (2009) propose that deontological and consequentialist (such as utilitarian) orientations are likely to affect the ethical evaluation of legitimacy lies. Specifically, they note that while a deontological orientation is likely to assess lying as intrinsically and absolutely wrong, a consequentialist orientation is more likely to be nuanced and is more likely to lead to rationalization of the proposed lie. In fact, $\mathrm{Xu}$ and $\mathrm{Ma}$ (2016) find individuals who view themselves as moral are more likely to prefer a deontological versus a consequentialist orientation. We therefore argue that entrepreneurs with a deontological orientation are more likely to assess the contemplated legitimacy lies as absolutely wrong, raise their self-sanctions, and therefore find it harder to morally disengage. We therefore propose the following:

Proposition 10a Entrepreneurs with higher levels of deontological orientation are less likely to activate a moral disengagement process. 
However, entrepreneurs with a consequentialist orientation are more likely to see the contemplated lie under a more nuanced light that considers the utilitarian outcome of actions (Chakrabarty and Bass 2015). Under such a perspective, self-sanctions would be loosened as benefit of the outcome may offset its costs which would provide the needed justification and clearly facilitate moral disengagement. We therefore propose the following:

Proposition 10b Entrepreneurs with higher levels of consequentialist orientation are more likely to activate a moral disengagement process.

\section{The Slippery Slope of Legitimacy Lies}

Despite their obvious importance, the dynamics of deception have received limited attention in the literature. ${ }^{8}$ One aspect of the dynamic nature of deception concerns its escalation over time and the other concerns the continuity or abruptness of such an escalation. These two aspects often get conflated, as in Levi's (2008) conceptualization of the slippery slope as the spiraling of deceptions. This perspective is widely shared since the escalation of corruption in organizations has been identified as being dynamic: the rationalization of an initial unethical act enables the enactment of a more serious corrupt act (Zyglidopoulos et al. 2009).

Fleming and Zyglidopoulos (2008) identify two escalation mechanisms among managers that are also relevant to our present focus: (a) the cover up of past lies, and (b) the routinization of deception rationalization. This is consistent with the view that individuals can become accustomed in employing moral disengagement resulting in habitual use that ultimately influences what they consider as being morally acceptable (Moore et al. 2019). Further, Garrett et al. (2016) offer a neurobiological basis for the slippery slope of deception as the human brain adapts to dishonesty; a gradual increase in self-serving deception is accompanied by a signal reduction in the amygdala.

Overall, in the slippery slope metaphor the ethical standards of the subject's behavior slip gradually after a series of small transgressions which escalate over time (Welsh et al. 2015) so it is not a single event that makes one come to the realization that they are acting unethically (Arjoon 2008). Finally, the fact that while sliding down the slippery slope the subject becomes unaware of the moral infractions (Campana 2016) indicates that the slippery slope dynamic induces forgetting of moral rules. In particular, prior cheating leads

\footnotetext{
${ }^{8}$ We would like to acknowledge the contribution of an anonymous reviewer who encouraged us to develop our theoretical model in this direction.
}

to the forgetting of moral rules and ethical boundaries (Shu and Gino 2012) and makes subsequent moral disengagement more likely (Shu et al. 2011). This has led researchers to explicitly refer to the existence of a positive "feedback loop" when describing the psychological mechanism of the slippery slope in general (Corner et al. 2011) or in the context of moral disengagement (Moore and Gino 2015; Shu and Gino 2012; Shu et al. 2011) and escalation of deception (Fleming and Zyglidopoulos 2008). Thus, a positive relationship between legitimacy lies and subsequent moral disengagement is expected, leading us to propose that:

Proposition 11 Prior legitimacy lies will have a gradual positive effect on the moral disengagement of subsequent legitimacy lies.

The above proposition is reflected in our conceptual model with a path from (previous) legitimacy lies to the (current) contemplation to morally disengage for a new legitimacy lie (see Fig. 1).

\section{Discussion}

\section{Overview}

On the surface, the premise that entrepreneurs should not tell lies seems defensible. However, this is not always the case. It is clear from the literature that entrepreneurs, at times, do lie to stakeholders in order to take a step closer to being viewed as legitimate-and these legitimacy lies are not at all well understood. As Fassin (2005) notes, as entrepreneurs desire to win, some individuals will avoid failure in every possible way available. He further maintains that, in the face of a crisis, otherwise honest entrepreneurs may be tempted to behave unethically as it might be the "least worse option" (p. 271). Therefore, our aim was to develop a model that could help enhance our understanding of unethical decision-making in the context of entrepreneurial new ventures by exploring individual and situational factors that affect moral disengagement and enable the delivery of legitimacy lies. We also address the call for paying attention to how people actually behave unethically, rather than how people should think about their behavior, which is the subject area of normative ethics (Bazerman and Gino 2012). Overall, we anticipate that our theorizing will provide an ample foundation from which multiple lines of inquiry can proceed.

\section{Theoretical Implications}

Here, we outline our primary contributions to the literature. First, we develop a novel theoretical model which helps us understand how an otherwise honest entrepreneur may 
engage in legitimacy lies. This model recognizes both the mediating role of moral disengagement as a process and also the effect of the entrepreneur's propensity to morally disengage. We also identify multiple situational and individual factors relevant to a new venture context based on a review of entrepreneurial leadership issues (Kuratko 2007). While our list is certainly not exhaustive, we aim to explain how these factors may lead to an increased likelihood of moral disengagement. We, thus, hope that our work will stimulate more research that can empirically test the propositions presented as well as develop others. Our work also has the propensity to stimulate the empirical testing of more dynamic models, in order to explain the slippery slope of entrepreneurial deception in ways complementary to those of the study of the escalation of deception in organizations (Fleming and Zyglidopoulos 2008). This is particularly important, since we know that smaller lies may lead to larger ones (Garrett et al. 2016).

Second, we contribute to the entrepreneurial ethics literature which has primarily focused on ethical decision-making processes rather than unethical decision-making (Treviño et al. 2014). In particular, we address how the context of nascent ventures presents unique challenges due to the lack of legitimacy of these organizations. This is critical since ethical or unethical behavior depends, to a large extent, on the specific context and individual perceptions (Carlson and Kacmar 1997). Here, our work more fully integrates the extant literature to accommodate a nuanced approach that provides greater clarity in terms of unethical decisionmaking - and, as startups and new ventures are the growth engine of individual economies, deepening our understanding of their unethical behavior is imperative.

\section{Practical Implications}

On a more practical note, we provide a framework for stakeholders who may now better understand how honest entrepreneurs are capable of engaging in deceptive practices. Pollack and Bosse (2014) explored how and why investors may forgive entrepreneurs for lying, but they missed a large piece of the puzzle in that the reasons for telling the lie in the first place can be predicted. By providing valuable insights on mechanisms of entrepreneurial deception, entrepreneurs may gain the ability to self-reflect and refrain from rationalizing an act they recognize as deceptive and, thus, reduce legitimacy lies. Further, stakeholders may take diagnostic, preemptive, and preventative measures in order to minimize moral disengagement and its resulting deception. Here, even if they fail in their interventions, by diagnosing the situation more accurately, investors and other stakeholders may at least be more prepared to receive and deal with entrepreneurial deception.
A way to decrease moral disengagement is to increase moral intensity. Specifically, a more personal approach from stakeholders would increase proximity to the entrepreneur and, therefore, increase moral intensity, reducing the possibility of dehumanization in any moral disengagement process. For example, VCs may explain that by being forced to discount (i.e., due to moral hazard and information asymmetry) what entrepreneurs communicate they might even discount truths, which is harmful for the venture and the entrepreneurs. They also need to point out that the magnitude of the effect and probability of the harm caused by entrepreneurial deception is large for them in financial and reputational terms. Similarly, FFFs (Friends, Fools, and Family), board members, business partners, and customers need to emphasize the non-trivial financial and relational impact on them if the information provided is not accurate.

As entrepreneurs are more likely to engage in deception if they feel that its impact is far out in the future, stakeholders could also emphasize, preemptively, the immediacy of the effect that lies may have on them. For example, customers can explain the immediate impact the product has if it does not meet the promised specifications or delivery dates. Further, investors need to demonstrate that they take a serious view about entrepreneurial lies by proactively raising moral awareness in early meetings and engaging in preemptive interventions such as priming (e.g., signing a code of ethics early on) which can reduce unethical behavior (Shu et al. 2011, 2012).

Stakeholders may also seek to diagnose individual entrepreneurial characteristics such as risk-taking, immoral imagination, or pronounced love of money in order to predict the likelihood that they may become victims of legitimacy lies. Similarly, they need to be particularly vigilant with entrepreneurs with signs of Machiavellianism or psychopathy which are characteristics often found among leaders and successful entrepreneurs. If investors choose to fund such entrepreneurs, they should expect and prepare for the eventuality of being victims of legitimacy lies. The challenge remains in identifying these traits or any other correlates that might be more easily detectable. For example, sensation seeking has long been known to be a strong predictor of risky behavior (Horvath and Zuckerman 1993) and to relate to psychopathy (Levenson et al. 1995). Interestingly, sensation seeking CEOs (e.g., private plane pilots) are more risk-taking and innovative (Sunder et al. 2017), but are at the same time have lower financial reporting quality and a higher likelihood of accounting fraud (Lobo et al. 2018).

Overall, investors select teams based on their ability to do what it takes in order to be able to deliver and properly execute on the business plan presented. However, given the resource constrained conditions of the venture and the considerable informational asymmetry present, the ethically savvy investor should be apprehensive about investing in 
teams that do whatever it takes. As such, our model contributes to new venture practice by providing a wide range of factors that can affect moral disengagement, with the purpose of reducing deception.

\section{Limitations and Directions for Future Research}

We present a conceptual model which includes a number of factors that have been identified as challenges for entrepreneurial leadership (Kuratko 2007). However, this list is not exhaustive and future research can examine a wider range of potentially relevant factors-and, related, even the differences between situational and individual factors may not always be clear (e.g., passion, risk) and may also interact. Moreover, as we have already alluded to, the effects presented in our model may be nuanced with respect to the type of stakeholder and the relationship between the entrepreneur and stakeholder - and the types of lies may have some varying gradation of intensity. Further, the model lends itself to empirical testing that could provide additional validation for the proposed relationships. It would also be intriguing to longitudinally study a large cohort of nascent ventures and examine the phenomenon of legitimacy lies over time. Such an exploration could examine the gradual nature of the slippery slope (Garrett et al. 2016; Shu et al. 2011) and the routinization of legitimacy lies (Fleming and Zyglidopoulos 2008) against the possibility of more abrupt changes in moral behavior (Köbis et al. 2017). This implies that the nature of the "feedback loop" leading to the slippery slope might be more nuanced than shown in our model and may itself depend on other factors.

Our model's implications on legitimacy lies need to be further refined in order to better account for the different stakeholders and their ability to protect themselves. For example, investors with less experience might be more vulnerable relative to professional investors who have extensive experience in managing investment portfolios. Similarly, customers who are less capable of performing the necessary due diligence may more easily fall victims of legitimacy lies. Employees as minority shareholders may feel helpless and even trapped; this may depend on the time and effort they have invested in the new venture where they may also be called to engage in legitimacy lies in front of customers and investors. Possibly, new venture employees or partners may have their own legitimacy lies threshold limit for the amount of unethical practices they are willing to withstand; above a certain level they may become more likely to exit the firm depending on their own morality.

Further, it is possible that some or all of the eight types of moral disengagement presented in Table 1 may affect the relationships theorized in the propositions above in different degrees. For instance, we can see how the lack of empathy that characterizes psychopathy or Machiavellianism may be more influential on moral disengagement that takes the form of blaming the victim or dehumanization rather than palliative comparison or minimization of consequences. We believe that such thinking-in addition to examining how the bright side such as need for achievement, commitment, perseverance-could provide a setting for considerable analytical depth and may be a fruitful line of future inquiry. Finally, the pitching process for raising capital resembles lies in a sales context-and, accordingly, the integration of sales ethics literature could further inform the literature on entrepreneurial ethics. ${ }^{9}$

\section{Compliance with Ethical Standards}

Conflict of interest The authors declare that they have no conflict of interest.

Research Involving Human Participants or Animals This article does not contain any studies with human participants or animals performed by any of the authors.

Open Access This article is licensed under a Creative Commons Attribution 4.0 International License, which permits use, sharing, adaptation, distribution and reproduction in any medium or format, as long as you give appropriate credit to the original author(s) and the source, provide a link to the Creative Commons licence, and indicate if changes were made. The images or other third party material in this article are included in the article's Creative Commons licence, unless indicated otherwise in a credit line to the material. If material is not included in the article's Creative Commons licence and your intended use is not permitted by statutory regulation or exceeds the permitted use, you will need to obtain permission directly from the copyright holder. To view a copy of this licence, visit http://creativecommons.org/licenses/by/4.0/.

\section{References}

Aguilera, R. V., \& Vadera, A. K. (2008). The dark side of authority: Antecedents, mechanisms, and outcomes of organizational corruption. Journal of Business Ethics, 77(4), 431-449.

Akhtar, R., Ahmetoglu, G., \& Chamorro-Premuzic, T. (2013). Greed is good? Assessing the relationship between entrepreneurship and subclinical psychopathy. Personality and Individual Differences, 54(3), 420-425.

Alboher, M. (2008, Oct 22). The Care and Feeding of Entrepreneurs. The New York Times. Retrieved from https://www.nytim es.com/2008/10/26/business/smallbusiness/26shifting.html

Aquino, K., \& Reed, I. (2002). The self-importance of moral identity. Journal of Personality and Social Psychology, 83(6), 1423.

Ariely, D. (2008). How honest people cheat. Harvard Business Review, $86(2), 24$

Arjoon, S. (2008). Slippery when wet: The real risk in business. Journal of Markets \& Morality, 11(1), 77-91.

Ashforth, B. E., \& Anand, V. (2003). The normalization of corruption in organizations. Research in Organizational Behavior, 25(25), $1-52$.

$\overline{9}$ We thank an anonymous reviewer for this comment. 
Babiak, P., Neumann, C. S., \& Hare, R. D. (2010). Corporate psychopathy: Talking the walk. Behavioral Sciences \& the Law, 28(2), 174-193. https://doi.org/10.1002/bs1.925.

Bandura, A. (1986). Social foundations of thought and action. PrenticeHall, NJ: Englewood Cliffs.

Bandura, A. (1999). Moral disengagement in the perpetration of inhumanities. Personality \& Social Psychology Review (Lawrence Erlbaum Associates), 3(3), 193.

Bandura, A., Barbaranelli, C., \& Caprara, G. V. (1996). Mechanisms of moral disengagement in the exercise of moral agency. Journal of Personality and Social Psychology, 71(2), 364-374. https://doi. org/10.1037/0022-3514.71.2.364.

Baron, R. A., Zhao, H., \& Miao, Q. (2015). Personal motives, moral disengagement, and unethical decisions by entrepreneurs: Cognitive mechanisms on the "Slippery Slope". Journal of Business Ethics, 128(1), 107-118. https://doi.org/10.1007/s1055 1-014-2078-y.

Baucus, M. S., Norton, W. I., Baucus, D. A., \& Human, S. E. (2008). Fostering creativity and innovation without encouraging unethical behavior. Journal of Business Ethics, 81(1), 97-115.

Baumeister, R. F. (1996). Evil: Inside human cruelty and violence. New York: WH Freeman/Times Books/Henry Holt \& Co.

Bazerman, M. H., \& Gino, F. (2012). Behavioral ethics: Toward a deeper understanding of moral judgment and dishonesty. Аnпиаl Review of Law and Social Science, 8, 85-104.

Beaussart, M. L., Andrews, C. J., \& Kaufman, J. C. (2013). Creative liars: The relationship between creativity and integrity. Thinking Skills and Creativity, 9, 129-134.

Benson, D. F., Brau, J. C., Cicon, J., \& Ferris, S. P. (2015). Strategically camouflaged corporate governance in IPOs: Entrepreneurial masking and impression management. Journal of Business Venturing, 30(6), 839-864. https://doi.org/10.1016/j.jbusv ent.2015.03.001.

Bitektine, A. (2011). Toward a theory of social judgments of organizations: The case of legitimacy, reputation, and status. Academy of Management Review, 36(1), 151-179.

Bitektine, A., \& Haack, P. (2015). The "macro" and the "micro" of legitimacy: Toward a multilevel theory of the legitimacy process. Academy of Management Review, 40(1), 49-75.

Bolino, M. C., \& Turnley, W. H. (2003). More than one way to make an impression: Exploring profiles of impression management. Journal of Management, 29(2), 141-160.

Brandstätter, H. (2011). Personality aspects of entrepreneurship: A look at five meta-analyses. Personality and Individual Differences, 51(3), 222-230. https://doi.org/10.1016/j.paid.2010.07.007.

Brenkert, G. G. (2009). Innovation, rule breaking and the ethics of entrepreneurship. Journal of Business Venturing, 24(5), 448464. https://doi.org/10.1016/j.jbusvent.2008.04.004.

Bruderl, J., \& Schussler, R. (1990). Organizational mortality: The liabilities of newness and adolescence. Administrative Science Quarterly, 530-547.

Bryant, P. (2009). Self-regulation and moral awareness among entrepreneurs. Journal of Business Venturing, 24(5), 505-518. https ://doi.org/10.1016/j.jbusvent.2008.04.005.

Bucar, B., \& Hisrich, R. D. (2001). Ethics of business managers vs. entrepreneurs. Journal of Developmental Entrepreneurship, 6(1), 59.

Buchholz, R. A., \& Rosenthal, S. B. (2005). The spirit of entrepreneurship and the qualities of moral decision making: Toward a unifying framework. Journal of Business Ethics, 60(3), 307-315.

Campana, P. (2016). When rationality fails: Making sense of the 'slippery slope'to corporate fraud. Theoretical Criminology, 20(3), 322-339.

Cardon, M. S., Wincent, J., Singh, J., \& Drnovsek, M. (2009). The nature and experience of entrepreneurial passion. Academy of
Management Review, 34(3), 511-532. https://doi.org/10.5465/ AMR.2009.40633190.

Cardon, M. S., Zietsma, C., Saparito, P., Matherne, B. P., \& Davis, C. (2005). A tale of passion: New insights into entrepreneurship from a parenthood metaphor. Journal of Business Venturing, 20(1), 23-45. https://doi.org/10.1016/j.jbusvent.2004.01.002.

Carlson, D. S., \& Kacmar, K. M. (1997). Perceptions of ethics across situations: A view through three different lenses. Journal of Business Ethics, 16(2), 147-160. https://doi.org/10.1023/a:10179 65302686.

Cassar, G. (2007). Money, money, money? A longitudinal investigation of entrepreneur career reasons, growth preferences and achieved growth. Entrepreneurship Regional Development, 19(1), 89-107.

Castille, C. M., Buckner, J. E., \& Thoroughgood, C. N. (2018). Prosocial citizens without a moral compass? Examining the relationship between Machiavellianism and unethical pro-organizational behavior. Journal of Business Ethics, 149(4), 919-930.

Chakrabarty, S., \& Bass, A. E. (2015). Comparing virtue, consequentialist, and deontological ethics-based corporate social responsibility: Mitigating microfinance risk in institutional voids. Journal of Business Ethics, 126(3), 487-512.

Chen, J., Tang, T. L.-P., \& Tang, N. (2014). Temptation, monetary intelligence (love of money), and environmental context on unethical intentions and cheating. Journal of Business Ethics, 123(2), 197-219. https://doi.org/10.1007/s10551-013-1783-2.

Christie, R., \& Geis, F. L. (1970). Studies in machiavellianism. New York: Academic Press.

Conroy, S., Henle, C. A., Shore, L., \& Stelman, S. (2017). Where there is light, there is dark: A review of the detrimental outcomes of high organizational identification. Journal of Organizational Behavior, 38(2), 184-203. https://doi.org/10.1002/ job. 2164 .

Corner, A., Hahn, U., \& Oaksford, M. (2011). The psychological mechanism of the slippery slope argument. Journal of Memory and Language, 64(2), 133-152.

Côté, S., Decelles, K. A., McCarthy, J. M., Van Kleef, G. A., \& Hideg, I. (2011). The Jekyll and Hyde of emotional intelligence: Emotion-regulation knowledge facilitates both prosocial and interpersonally deviant behavior. Psychological science, 22(8), 1073. https://doi.org/10.1177/0956797611416251.

Covin, J. G., \& Slevin, D. P. (1989). Strategic management of small firms in hostile and benign environments. Strategic Management Journal, 10(1), 75-87.

Croce, A., Tenca, F., \& Ughetto, E. (2017). How business angel groups work: Rejection criteria in investment evaluation. International Small Business Journal, 35(4), 405-426.

Cropley, D. H., Kaufman, J. C., \& Cropley, A. J. (2013). Understanding malevolent creativity. In K. Thomas \& J. Chan (Eds.), Handbook of research on creativity. Northampton, MA: Edward Elgar.

Dahling, J. J., Whitaker, B. G., \& Levy, P. E. (2009). The development and validation of a new Machiavellianism Scale. Journal of Management, 35(2), 219-257. https://doi.org/10.1177/01492 06308318618 .

De Clercq, D., \& Voronov, M. (2009). Toward a practice perspective of entrepreneurship: Entrepreneurial legitimacy as habitus. International Small Business Journal, 27(4), 395-419.

de Vries, M. F. R. K. (1977). The entrepreneurial personality: A person at the crossroads. Journal of Management Studies, 14(1), 34-57.

de Vries, M. F. R. K. (1985). The dark side of entrepreneurship. Harvard Business Review(November-December), 160-167.

de Vries, M. F. R. K., \& Miller, D. (1985). Narcissism and leadership: An object relations perspective. Human Relations, 38(6), 583-601. https://doi.org/10.1177/001872678503800606.

Delmar, F., \& Shane, S. (2004). Legitimating first: Organizing activities and the survival of new ventures. Journal of Business Venturing, 19(3), 385-410. 
Drover, W., Wood, M. S., \& Fassin, Y. (2014). Take the money or run? Investors' ethical reputation and entrepreneurs' willingness to partner. Journal of Business Venturing, 29(6), 723-740. https:// doi.org/10.1016/j.jbusvent.2013.08.004.

Egan, V., Hughes, N., \& Palmer, E. J. (2015). Moral disengagement, the dark triad, and unethical consumer attitudes. Personality and Individual Differences, 76, 123-128.

Fassin, Y. (2005). The Reasons Behind Non-Ethical Behaviour in Business and Entrepreneurship. Journal of Business Ethics, 60(3), 265-279. https://doi.org/10.1007/s10551-005-0134-3.

Fassin, Y., \& Drover, W. (2017). Ethics in entrepreneurial finance: Exploring problems in venture partner entry and exit. Journal of Business Ethics, 140(4), 649-672.

Feifer, J. (2018, Nov. 1). Should Entrepreneurs Lie? It's a Tricky Question. Entrepreneur. Retrieved from https://www.entreprene ur.com/article/321494

Fleming, P., \& Zyglidopoulos, S. C. (2008). The escalation of deception in organizations. Journal of Business Ethics, 81(4), 837-850.

Garrett, N., Lazzaro, S. C., Ariely, D., \& Sharot, T. (2016). The brain adapts to dishonesty. Nature Neuroscience, 19(12), 1727-1732. https://doi.org/10.1038/nn.4426.

Garud, R., Schildt, H. A., \& Lant, T. K. (2014). Entrepreneurial storytelling, future expectations, and the paradox of legitimacy. Organization Science, 25(5), 1479-1492. https://doi.org/10.1287/ orsc.2014.0915.

Gino, F., \& Ariely, D. (2012). The dark side of creativity: Original thinkers can be more dishonest. Journal of Personality and Social Psychology, 102(3), 445.

Gino, F., \& Margolis, J. D. (2011). Bringing ethics into focus: How regulatory focus and risk preferences influence (un) ethical behavior. Organizational Behavior and Human Decision Processes, 115(2), 145-156.

Gino, F., \& Wiltermuth, S. S. (2014). Evil genius? How dishonesty can lead to greater creativity. Psychological science, 25(4), 973-981.

Goncalo, J. A., Flynn, F. J., \& Kim, S. H. (2010). Are two narcissists better than one? The link between narcissism, perceived creativity, and creative performance. Personality \& social psychology bulletin, 36(11), 1484. https://doi.org/10.1177/014616721038510 9.

Harris, J. D., Sapienza, H. J., \& Bowie, N. E. (2009). Ethics and entrepreneurship. Journal of Business Venturing, 24(5), 407-418. https://doi.org/10.1016/j.jbusvent.2009.06.001.

Haslam, N. (2006). Dehumanization: An integrative review. Personality and Social Psychology Review, 10(3), 252-264.

Haynes, K. T., Hitt, M. A., \& Campbell, J. T. (2015). The dark side of leadership: Towards a mid-range theory of hubris and greed in entrepreneurial contexts. Journal of Management Studies, 52(4), 479-505.

Hmieleski, K. M., \& Lerner, D. A. (2016). The dark triad and nascent entrepreneurship: An examination of unproductive versus productive entrepreneurial motives. Journal of Small Business Management, 54(S1), 7-32.

Ho, V. T., \& Pollack, J. M. (2014). Passion Isn't Always a Good Thing: Examining Entrepreneurs' Network Centrality and Financial Performance with a Dualistic Model of Passion. Journal of Management Studies, 51(3), 433-459. https://doi.org/10.1111/ joms. 12062 .

Horvath, P., \& Zuckerman, M. (1993). Sensation seeking, risk appraisal, and risky behavior. Personality and Individual Differences, 14(1), 41-52.

Jones, G. E., \& Kavanagh, M. J. (1996). An experimental examination of the effects of individual and situational factors on unethical behavioral intentions in the workplace. Journal of Business Ethics, 15(5), 511-523. https://doi.org/10.1007/bf00381927.
Jones, T. M. (1991). Ethical decision-making by individuals in organizations-An issue-contingent model. Academy of Management Review, 16(2), 366-395. https://doi.org/10.2307/258867.

Kale, S., \& Arditi, D. (1998). Business failures: Liabilities of newness, adolescence, and smallness. Journal of Construction engineering and management, 124(6), 458-464.

Karmann, T., Mauer, R., Flatten, T. C., \& Brettel, M. (2016). Entrepreneurial orientation and corruption. Journal of Business Ethics, 133(2), 223-234.

Katuoka, S., \& Navickaitė-Sakalauskienė, I. (2016). Misleading actions vs. misleading omissions under Unfair Commercial Practices Directive. National approach in context. International Comparative Jurisprudence, 2(1), 18-24.

Kessler, S. R., Bandelli, A. C., Spector, P. E., Borman, W. C., Nelson, C. E., \& Penney, L. M. (2010). Re-examining machiavelli: A three-dimensional model of machiavellianism in the workplace. Journal of Applied Social Psychology, 40(8), 1868-1896. https ://doi.org/10.1111/j.1559-1816.2010.00643.x.

Kish-Gephart, J. J., Harrison, D. A., \& Treviño, L. K. (2010). Bad apples, bad cases, and bad barrels: Meta-analytic evidence about sources of unethical decisions at work. Journal of Applied Psychology, 95(1), 1-31.

Köbis, N. C., van Prooijen, J.-W., Righetti, F., \& Van Lange, P. A. (2017). The road to bribery and corruption: Slippery slope or steep cliff? Psychological science, 28(3), 297-306.

Kong, D. T. (2016). The pathway to unethical pro-organizational behavior: Organizational identification as a joint function of work passion and trait mindfulness. Personality and Individual Differences, 93, 86-91. https://doi.org/10.1016/j. paid.2015.08.035.

Kriss, P. H., Nagel, R., \& Weber, R. A. (2013). Implicit vs. explicit deception in ultimatum games with incomplete information. Journal of Economic Behavior \& Organization, 93, 337-346.

Kuratko, D. F. (2007). Entrepreneurial leadership in the 21st century: Guest editor's perspective. Journal of Leadership Organizational Studies, 13(4), 1-11.

Leutner, F., Ahmetoglu, G., Akhtar, R., \& Chamorro-Premuzic, T. (2014). The relationship between the entrepreneurial personality and the Big Five personality traits. Personality and Individual Differences, 63, 58-63. https://doi.org/10.1016/j. paid.2014.01.042.

Levenson, M. R., Kiehl, K. A., \& Fitzpatrick, C. M. (1995). Assessing psychopathic attributes in a noninstitutionalized population. Journal of Personality and Social Psychology, 68(1), 151.

Levi, M. (2008). The phantom capitalists. Aldershot, UK: Ashgate.

Lobo, G., Ouyang, B., Wang, C., \& Zhou, J. (2018). CEO Sensation Seeking and Financial Reporting Quality. Paper presented at the Hawai'i Accounting Research Conference (HARC), Hawaii.

Lounsbury, M., \& Glynn, M. A. (2001). Cultural entrepreneurship: Stories, legitimacy, and the acquisition of resources. Strategic Management Journal, 22(6-7), 545-564. https://doi.org/10.1002/ smj. 188.

Martens, M. L., Jennings, J. E., \& Jennings, P. D. (2007). Do the stories they tell get them the money they need? The role of entrepreneurial narratives in resource acquisition. Academy of Management Journal, 50(5), 1107-1132.

Martin, C. W. (2009). The philosophy of deception. Oxford: Oxford University Press on Demand.

McVea, J. F. (2009). A field study of entrepreneurial decision-making and moral imagination. Journal of Business Venturing, 24(5), 491-504. https://doi.org/10.1016/j.jbusvent.2008.07.003.

Miller, D. (2015). A downside to the entrepreneurial personality? Entrepreneurship Theory and Practice, 39(1), 1-8. https://doi. org/10.1111/etap.12130. 
Miska, C., Stahl, G. K., \& Fuchs, M. (2018). The moderating role of context in determining unethical managerial behavior: A case survey. Journal of Business Ethics, 153(3), 793-812.

Moberg, D. J., \& Seabright, M. A. (2000). The development of moral imagination. Business ethics quarterly, 10(4), 845-884.

Moore, C. (2015). Moral disengagement. Current Opinion in Psychology, 6, 199-204. https://doi.org/10.1016/j.copsyc.2015.07.018.

Moore, C., Detert, J. R., Trevino, L. K., Baker, V. L., \& Mayer, D. M. (2012). Why employees do bad things: Moral disengagement and unethical organizational behavior. Personnel Psychology, 65(1), 1-48. https://doi.org/10.1111/j.1744-6570.2011.01237.x.

Moore, C., \& Gino, F. (2015). Approach, ability, aftermath: A psychological process framework of unethical behavior at work. The Academy of Management Annals, 9(1), 235-289.

Moore, C., Mayer, D. M., Chiang, F. F., Crossley, C., Karlesky, M. J., \& Birtch, T. A. (2019). Leaders matter morally: The role of ethical leadership in shaping employee moral cognition and misconduct. Journal of Applied Psychology, 104(1), 123.

Morris, M. H., Schindehutte, M., Walton, J., \& Allen, J. (2002). The ethical context of entrepreneurship: Proposing and testing a developmental framework. Journal of Business Ethics, 40(4), 331-361. https://doi.org/10.1023/a:1020822329030.

Murnieks, C. Y., Cardon, M. S., Sudek, R., White, T. D., \& Brooks, W. T. (2016). Drawn to the fire: The role of passion, tenacity and inspirational leadership in angel investing. Journal of Business Venturing, 31(4), 468-484. https://doi.org/10.1016/j.jbusv ent.2016.05.002.

Nagy, B. G., Pollack, J. M., Rutherford, M. W., \& Lohrke, F. T. (2012). The influence of entrepreneurs' credentials and impression management behaviors on perceptions of new venture legitimacy. Entrepreneurship Theory and Practice, 36(5), 941-965. https:// doi.org/10.1111/j.1540-6520.2012.00539.x.

Neubaum, D., Mitchell, M., \& Schminke, M. (2004). Firm newness, entrepreneurial orientation, and ethical climate. Journal of Business Ethics, 52(4), 335-347.

Nussbaum, M. C. (1995). Objectification. Philosophy \& Public Affairs, 24(4), 249-291.

O'Neil, I., \& Ucbasaran, D. (2016). Balancing "what matters to me" with "what matters to them": Exploring the legitimation process of environmental entrepreneurs. Journal of Business Venturing, $31(2), 133-152$.

O'Fallon, M. J., \& Butterfield, K. D. (2005). A review of the empirical ethical decision-making literature: 1996-2003. Journal of Business Ethics, 59(4), 375-413.

Ormerod, D., \& Laird, K. (2018). Smith, Hogan, and Ormerod's Criminal Law. Oxford: Oxford University Press.

Parhankangas, A., \& Ehrlich, M. (2014). How entrepreneurs seduce business angels: An impression management approach. Journal of Business Venturing, 29(4), 543-564. https://doi.org/10.1016/j. jbusvent.2013.08.001.

Paulhus, D. L., \& Williams, K. M. (2002). The dark triad of personality: Narcissism, Machiavellianism, and psychopathy. Journal of research in personality, 36(6), 556-563.

Pollack, J. M., Barr, S., \& Hanson, S. (2017). New venture creation as establishing stakeholder relationships: A trust-based perspective. Journal of Business Venturing Insights, 7, 15-20.

Pollack, J. M., \& Bosse, D. A. (2014). When do investors forgive entrepreneurs for lying? Journal of Business Venturing, 29(6), 741-754. https://doi.org/10.1016/j.jbusvent.2013.08.005.

Pollack, J. M., Rutherford, M. W., \& Nagy, B. G. (2012). Preparedness and cognitive legitimacy as antecedents of new venture funding in televised business pitches. Entrepreneurship Theory and Practice, 36(5), 915-939.

Rawwas, M. Y., Swaidan, Z., \& Oyman, M. (2005). Consumer ethics: A cross-cultural study of the ethical beliefs of Turkish and American consumers. Journal of Business Ethics, 57(2), 183-195.
Rest, J. R. (1986). Moral development: Advances in research and theory. New York: Praeger Publishers.

Rezaee, Z. (2005). Causes, consequences, and deterence of financial statement fraud. Critical Perspectives on Accounting, 16(3), 277-298.

Ribeaud, D., \& Eisner, M. (2010). Are moral disengagement, neutralization techniques, and self-serving cognitive distortions the same? Developing a unified scale of moral neutralization of aggression. International Journal of Conflict and Violence, 4(2), 298-315.

Roeser, K., McGregor, V. E., Stegmaier, S., Mathew, J., Kübler, A., \& Meule, A. (2016). The Dark Triad of personality and unethical behavior at different times of day. Personality and Individual Differences, 88, 73-77.

Rogers, T., Zeckhauser, R., Gino, F., Norton, M. I., \& Schweitzer, M. E. (2017). Artful paltering: The risks and rewards of using truthful statements to mislead others. Journal of Personality and Social Psychology, 112(3), 456.

Rutherford, M. W., \& Buller, P. F. (2007). Searching for the legitimacy threshold. Journal of Management Inquiry, 16(1), 78-92. https ://doi.org/10.1177/1056492606297546.

Rutherford, M. W., Buller, P. F., \& Stebbins, J. M. (2009). Ethical considerations of the legitimacy lie. Entrepreneurship Theory and Practice, 33(4), 949-964. https://doi.org/10.111 1/j.1540-6520.2009.00310.x.

Rutherford, M. W., Tocher, N., Pollack, J. M., \& Coombes, S. M. (2016). Proposing a financial legitimacy threshold in emerging ventures: A multi-method investigation. Group \& Organization Management, 41(6), 751-785.

Schwartz, M. S. (2016). Ethical decision-making theory: An Integrated approach. Journal of Business Ethics, 139(4), 755-776. https://doi.org/10.1007/s10551-015-2886-8.

Seabright, M. A., \& Schminke, M. (2002). Immoral imagination and revenge in organizations. Journal of Business Ethics, 38(1), $19-31$.

Shu, L. L., \& Gino, F. (2012). Sweeping dishonesty under the rug: How unethical actions lead to forgetting of moral rules. Journal of Personality and Social Psychology, 102(6), 1164.

Shu, L. L., Gino, F., \& Bazerman, M. H. (2011). Dishonest deed, clear conscience: When cheating leads to moral disengagement and motivated forgetting. Personality \& social psychology bulletin, 37(3), 330. https://doi.org/10.1177/0146167211398138.

Shu, L. L., Mazar, N., Gino, F., Ariely, D., \& Bazerman, M. H. (2012). Signing at the beginning makes ethics salient and decreases dishonest self-reports in comparison to signing at the end. Proceedings of the National Academy of Sciences, 109(38), 15197. https://doi.org/10.1073/pnas.1209746109.

Singh, J. V., Tucker, D. J., \& House, R. J. (1986). Organizational legitimacy and the liability of newness. Administrative Science Quarterly, 31(2), 171-193. https://doi.org/10.2307/2392787.

Smilor, R. W. (1997). Entrepreneurship: Reflections on a subversive activity. Journal of Business Venturing, 12(5), 341-346. https ://doi.org/10.1016/S0883-9026(97)00008-6.

Smith, R., \& Anderson, A. R. (2004). The devil is in the e-tale: form and structure in the entrepreneurial narrative. In D. Hjorth \& C. Steyaert (Eds.), Narrative discursive approaches in entrepreneurship (pp. 125-143). New York: Edward Elgar.

Sternberg, R. J., \& Lubart, T. I. (1995). Defying the crowd: Cultivating creativity in a culture of conformity. New York: Free Press.

Suchman, M. C. (1995). Managing legitimacy-Strategic and institutional approaches. Academy of Management Review, 20(3), 571-610. https://doi.org/10.2307/258788.

Suddaby, R., Bitektine, A., \& Haack, P. (2017). Legitimacy. Academy of Management Annals, 11(1), 451-478.

Sulloway, F. J. (1996). Born to rebel: Birth order, family dynamics, and creative lives. New York: Pantheon Books. 
Sunder, J., Sunder, S. V., \& Zhang, J. (2017). Pilot CEOs and corporate innovation. Journal of Financial Economics, 123(1), 209-224.

Sykes, G. M., \& Matza, D. (1957). Techniques of neutralization-A theory of delinquency. American Sociological Review, 22(6), 664-670. https://doi.org/10.2307/2089195.

Tang, T. L.-P., \& Chiu, R. K. (2003). Income, money ethic, pay satisfaction, commitment, and unethical behavior: Is the love of money the root of evil for Hong Kong employees? J Journal of business ethics, 46(1), 13-30.

Teal, E. J., \& Carroll, A. B. (1999). Moral reasoning skills: Are entrepreneurs different? Journal of Business Ethics, 19(3), 229-240.

Treviño, L. K., den Nieuwenboer, N. A., \& Kish-Gephart, J. J. (2014). (Un) ethical behavior in organizations. Annual Review of Psychology, 65, 635-660.

Twenge, J. M., Konrath, S., Foster, J. D., Keith Campbell, W., \& Bushman, B. J. (2008). Egos inflating over time: A cross-temporal meta-analysis of the narcissistic personality inventory. Journal of Personality, 76(4), 875-902. https://doi.org/10.111 1/j.1467-6494.2008.00507.x.

Uberbacher, F. (2014). Legitimation of new ventures: A review and research programme. Journal of Management Studies, 51(4), 667-698. https://doi.org/10.1111/joms.12077.

Vallerand, R. J., Blanchard, C., Mageau, G. A., Koestner, R., Ratelle, C., Léonard, M., et al. (2003). Les passions de l'ame: on obsessive and harmonious passion. Journal of Personality and Social Psychology, 85(4), 756-767.

Wales, W. J., Patel, P. C., \& Lumpkin, G. T. (2013). In Pursuit of Greatness: CEO Narcissism, Entrepreneurial Orientation, and Firm Performance Variance. Journal of Management Studies, 50(6), 1041-1069. https://doi.org/10.1111/joms.12034.

Wang, X., \& Krumhuber, E. G. (2017). The love of money results in objectification. British Journal of Social Psychology, 56(2), 354-372.
Weiss, B., \& Feldman, R. S. (2006). Looking good and lying to do it: Deception as an impression management strategy in job interviews. Journal of Applied Social Psychology, 36(4), 1070-1086.

Welsh, D. T., Ordóñez, L. D., Snyder, D. G., \& Christian, M. S. (2015). The slippery slope: How small ethical transgressions pave the way for larger future transgressions. Journal of Applied Psychology, $100(1), 114$.

Xu, Z. X., \& Ma, H. K. (2016). How can a deontological decision lead to moral behavior? The moderating role of moral identity. Journal of Business Ethics, 137(3), 537-549.

Zerbe, W. J., \& Paulhus, D. L. (1987). Socially desirable responding in organizational behavior: A reconception. Academy of Management Review, 12(2), 250-264.

Zimmerman, M. A., \& Zeitz, G. J. (2002). Beyond survival: Achieving new venture growth by building legitimacy. Academy of Management Review, 27(3), 414-431. https://doi.org/10.2307/4134387.

Zott, C., \& Huy, Q. N. (2007). How entrepreneurs use symbolic management to acquire resources. Administrative Science Quarterly, 52(1), 70-105. https://doi.org/10.2189/asqu.52.1.70.

Zuo, S., Wang, F., Xu, Y., Wang, F., \& Zhao, X. (2016). The fragile but bright facet in the Dark Gem: Narcissism positively predicts personal morality when individual's self-esteem is at low level. Personality and Individual Differences, 97, 272-276.

Zyglidopoulos, S. C., Fleming, P. J., \& Rothenberg, S. (2009). Rationalization, overcompensation and the escalation of corruption in organizations. Journal of Business Ethics, 84(1), 65-73.

Publisher's Note Springer Nature remains neutral with regard to jurisdictional claims in published maps and institutional affiliations. 